\title{
Avian Cytokines in Health and Disease
}

Author(s)

Wigley $\mathrm{P}^{1}$

Kaiser $\mathrm{P}^{1}$

1-Institute for Animal Health, Berkshire - UK

Mail Address

Paul Wigley

Institute for Animal Health

Compton

Newbury

Berkshire

RG20 7NN

United Kingdom

Email: paul.wigley@bbsrc.ac.uk

\section{Keywords}

cytokines, immunity, infectious disease, inflammation, vaccination

\section{Acknowledgments}

The authors wish to thank the Biotechnology and Biological Sciences Research Council UK for financial support, and M iss Abigail Lazzerine for use of her results.

\section{ABSTRACT}

Cytokines are proteins secreted by cells that play an important role in the activation and regulation of other cells and tissues during inflammation and immune responses. Although well described in several mammalian species, the role of cytokines and other related proteins is poorly understood in avian species. Recent advances in avian genetics and immunology have begun to allow the exploration of cytokines in health and disease. Cytokines may be classified in a number of ways, but may be conveniently arranged into four broad groups on the basis of their function. Proinflammatory cytokines such as interleukin- 6 and interleukin$1 \beta$ play a role in mediating inflammation during disease or injury. Th1 cytokines, including interleukin-12 and interferon- $\gamma$, are involved in the induction of cell-mediated immunity, whereas Th2 cytokines such as interleukin- 4 are involved in the induction of humoral immunity. The final group Th3 or Tr cytokines play a role in regulation of immunity. The role of various cytokines in infectious and non-infectious diseases of chickens and turkeys is now being investigated. Although there are only a few reliable ELISAs or bioassays developed for avian cytokines, the use of molecular techniques, and in particular quantitative RT-PCR (Taqman) has allowed investigation of cytokine responses in a number of diseases including salmonellosis, coccidiosis and autoimmune thyroiditis. In addition the use of recombinant cytokines as therapeutic agents or as vaccine adjuvants is now being explored.

\section{INTRODUCTION}

Cytokines are proteins or peptides secreted by cells that play a key role in immune and inflammatory responses through the activation and regulation of other cells and tissues. Their role in mammals is well defined, with a vast number of publications describing the structure of cytokines and their role in health and disease. In contrast, avian cytokines have been poorly defined, both in terms of structure and function. However, in recent years advances in avian immunology and genetics have lead to the discovery of a range of cytokines mainly in the chicken, but also in the turkey and other avian species. Although only relatively few recombinant cytokines or monoclonal antibodies against avian cytokines have yet been produced, the availability of new technologies such as real-time quantitative PCR allow the quantification of expression of messenger RNA from cytokine genes without the need for protein or antibody. This has opened up a large area of possibilities to determine cytokine levels in disease giving increased understanding of the mechanisms of both pathogenesis and immunity.

Cytokines also have enormous potential in the control of infectious disease in poultry. Their use as novel therapeutic agents in disease has 
begun to be explored. Cytokines may also have the potential to act as vaccine adjuvants that may specifically activate the immune system to produce effective protection. In this review we will discuss the structure and functions of cytokines, the main types of cytokines so far found in the chicken and their potential as adjuvants or therapeutic agents. We will also address some of the work that is determining the role of cytokines in the pathogenesis of infectious diseases such as salmonellosis and in other diseases such as autoimmune thyroiditis.

The main function of cytokines is in the activation and regulation of the cells of immune system. Cytokines are produced by a wide variety of cell types, though the type of cytokines produced varies enormously depending on the cell's function. For instance, epithelial cells may produce cytokines involved in the generation of inflammation, the so-called proinflammatory cytokines such as interleukin-6 (IL-6) or IL-8, whereas macrophages may produce both proinflammatory cytokines and cytokines involved in the activation and regulation of $T$ helper lymphocytes (Th) in the development of an adaptive immune response. All cytokines act through receptors on the surface of the target cells, which may lead to the activation or downregulation of the cell's activity. Cytokines have been classified into a number of groups based on their activity and the cells they are produced by or act upon. These groups include interleukins (IL), interferons (IFN), tumour necrosis factors (TNF), transforming growth factors (TGF), migratory inhibitory factors and the smaller chemokines. However, there is a considerable overlap between each of these categories. The names are often based on a particular property of cytokines, e.g. TNF was named for its ability to act upon tumours, and do not always reflect the pleiotropic effects of many cytokines. It is also possible to broadly categorise cytokines on their activity and this may be more beneficial in understanding the nature of their general activity. Table 1 shows the currently known

Table 1 - Currently described chicken cytokines classified on basis of function.

\begin{tabular}{l|c} 
Functional classification & $\begin{array}{c}\text { Described chicken cytokines } \\
\text { Pro-inflammatory }\end{array}$ \\
\hline Th1 & IL-1 $\beta$, IL-6, IL-8 \\
Th2 & Non- $\gamma$ IL-2, IL-18 \\
Th3/Tr1 & TGF- $\beta$ \\
\hline Others & IFN- $\alpha$, IFN- $\beta$, IL-15, IL-16, chemokines \\
\hline
\end{tabular}

chicken cytokines classified according to their properties. In this review, we will describe the currently known cytokines of chickens and other avian species, their structure, function and roles they play in disease processes. We will also outline their potential use in therapy or as vaccine adjuvants.

\section{PROINFLAMMATORY CYTOKINES}

\section{IL-1 $\beta$}

IL-1 $\beta$ in mammals is produced by a range of cells following stimulation, particularly by microbes or microbial products (Dinarello, 1998). The mature form of IL- $1 \beta$ has a molecular weight of $17 \mathrm{kDa}$ and is formed from a $31 \mathrm{kDa}$ precursor through the action of specific cellular proteases such as the interleukin $1 \alpha$ converting enzyme (ICE or caspase $1)$, which has also been implicated in mediating programmed cell death or apoptosis. Two receptors (IL-1R and IL-1R $)$ and an accessory protein (IL-1R$A C P)$ have been described in mammals. Binding of IL-1 $\beta$ to the receptors leads to signal transduction through the hydrolysis of GTP and the activation of M AP kinases. The biological activity of IL-1 $\beta$ is highly inflammatory, with its main function being to activate the immune system in an acute phase response. IL-1 $\beta$ activates a range of cells including macrophages and T lymphocytes that may thus lead to production of other cytokines and chemokines. However, as a consequence IL-1 $\beta$ leads to fever, hence its historical name 'endogenous pyrogen'. Under some circumstances its toxicity may lead to severe complications such as septic shock following bacterial infections in man.

In the chicken a cDNA encoding the chicken homologue of mammalian IL-1 $\beta$ was recently cloned by expression screening (Weining et al., 1998). Lipopolysaccharide (LPS) was used to stimulate HD11 cells (Beug et al., 1979), a chicken macrophage cell line, and resulted in the secretion of a substance with IL-1like bioactivity (Weining et al., 1998). Screening of a cDNA library constructed from RNA from the LPSactivated HD11 cells identified a sequence encoding a polypeptide with $25 \%$ similarity to human IL-13. Further study of the predicted polypeptide suggested that this was in fact the chicken homologue of mammalian IL$1 \beta$. Chicken IL-1 $\beta$ has a similar gene structure (five exons and four introns in the coding region of the gene) to mammalian homologues, and overall, the gene is approximately $1 / 4$ the size of mammalian IL-1 $\beta$ genes 
and maps to one end of chromosome 2 (Kaiser et al., 2001). The chicken type-I IL-1 receptor (IL-1R) (Guida et al., 1992) has $60 \%$ amino acid (aa) identity with human and mouse IL-1R, with the intracellular component most highly conserved, suggesting that the downstream signaling pathway is likely to be similar. Klasing and Peng (2001) expressed the ligand-binding domain of the chicken IL-1R (soluble (s) IL-1R) in yeast, and then raised polyclonal antisera to the recombinant in rabbits. The antisera neutralized the IL-1-like activity produced in the media of LPS-stimulated HD11 cells.

IL-1 $\beta$ production would be expected in many avian infections where a pro-inflammatory response occurs, as is the case with mammalian models of infection. This has been shown in protozoal infections of chickens where expression of IL-1 $\beta$ mRNA in the gut has been shown to increase 80 -fold seven days after Eimeria tenella infection, through the use of a quantitative RTPCR technique (Laurent et al., 2001). An increase, but to a lesser degree, was also found following E. maxima infection. Infection models have also been used to determine activity follow ing viral and bacterial infections in the chicken (Heggen et al., 2000; Kaiser et al., 2000). IL-1 activity was increased in macrophage supernatants from birds suffering from poult enteritis and mortality syndrome (PEMS) (Heggen et al., 2000). Conversely, following Salmonella enterica invasion in an in vitro cell culture system, IL-1 $\beta$ mRNA expression was generally decreased (Kaiser et al., 2000). How ever, it should be noted that IL-1 $\beta$ mRNA levels do not necessarily reflect release of biologically active protein.

\section{IL-6 and IL-6 family}

IL-6 is a multifunctional cytokine produced by a number of cell types and is involved in acute-phase responses, immune regulation and haematopoesis (Hirano, 1998). In mammals, production of IL- 6 following infection or other challenges induces acute phase proteins such as serum amyloid A, C-reactive protein (CRP) and $\alpha_{1}$-antitrypsin as part of an inflammatory response (Hirano, 1998). IL-6 has many effects on the immune system, including activation of $B$ and $T$ lymphocytes, and plays an important role in haematopoesis including the induction of macrophage production and development, acting synergistically with granulocyte-macrophage colony stimulating factor (GM CSF). M ammalian IL-6 is a glycoprotein with a molecular mass between 21 to $28 \mathrm{kDa}$. The receptor is formed from an $80 \mathrm{kDa}$ IL- 6 binding protein ( $\alpha$ chain) and gp130 ( $\beta$ chain), a $130 \mathrm{kDa}$ signal transducer. The gp130 subunit is a common subunit amongst other cytokine receptors, such as those for IL-11 and ciliary neurotrophic factor (CNTF), that together form the IL-6 family. Binding to the receptor leads to signal transduction via the JAKSTAT signal transduction pathway. The Janus ( $A K$ ) family of tyrosine kinases associate with and phosphorylate the gp130 subunit leading to activation of the signal transducer and activator of transcription (STAT) proteins. These act through several signal pathw ays that may lead to activation of the various functions of IL- 6 .

In the chicken a section of IL- 6 -like CDNA was identified in an expressed sequence tag (EST) library. ESTs are short DNA sequences (200-500 bp) of expressed genes and are useful tools in identifying specific genes. Chickens were orally treated with the synthetic immune modifier S-28463, which, in mammals, strongly induces expression of IFN- $\alpha$, tumour necrosis factor (TNF), IL-1, IL-8 and IL-6 (Tomai et al., 1995) and the spleens were used to isolate expressed mRNA. cDNA sequences were produced from the mRNA, one of which encoded a predicted protein with $35 \%$ aa identity with human IL-6 (Schneider et al., 2001). Recombinant chicken IL-6 induced proliferation of the IL-6-dependent murine hybridoma cell line 7TD1, and when injected into chickens, it induced an increase in serum corticosterone levels indicating induction of acute phase activity. Further investigation of the IL- 6 gene in the chicken has revealed a similar structure to that found in mammals (Kaiser et al., 2001).

IL- 6 activity has been found in several infectious diseases of chickens. IL- 6 is produced during both murine and chicken Eimeria infections (Lynagh et al., 2000), and IL- 6 activity, similarly to IL-1, was increased in macrophage supernatants from birds suffering from PEM S (Heggen et al., 2000). Interestingly the induction of an IL- 6 response may play a major role in the nature of the response to different serovars of Salmonella enterica in chickens (Kaiser et al., 2000). Invasion of chicken cells by serovars $\mathrm{S}$. Typhimurium or $\mathrm{S}$. Enteritidis results in an 8-fold increase of IL-6 mRNA determined by quantitative RT-PCR. Such activity in vivo would induce a strong inflammatory and immune response, limiting these serovars mainly to the gut and preventing development of systemic disease. In contrast, invasion by the avian specific serovar S. Gallinarum, does not lead to an increase of IL- 6 mRNA. This would result in little or no inflammation or induction of an immune response, allowing invasion to take place almost by 'stealth', subsequently allowing development of the systemic disease fowl typhoid.

A further member of the IL- 6 family of cytokines has 
been described in birds - growth promoting activity (GPA), which is thought to be equivalent to CNTF (Koshlukova et al., 1996). Cultured chick ciliary ganglion neurons possess receptors capable of binding both GPA and human CNTF, but GPA is up to five times more potent than human CNTF in promoting chick neuronal survival (Koshlukova et al., 1996).

\section{IL-8 and chemokines}

IL-8 is a member of a group of small structurally related cytokines that have chemotactic activity for specific leukocyte types and are termed chemokines (Wuyts et al., 1998). In humans there are two main subfamilies of cytokines: CXC chemokines that attract neutrophils and CC chemokines which attract lymphocytes, monocytes, eosinophils and basophils but not neutrophils. IL-8 is a CXC chemokine produced by a wide range of cell types including epithelial and endothelial cells. IL-8 was initially described as neurophil activating factor, which clearly describes its activity. Human IL-8 is initially formed as a 99 aa protein including a 22 aa signal sequence that is cleaved to give rise to a 77 aa active form. It would appear that the primary function of IL-8 is to recruit and activate neutrophils in response to infection. However, IL-8 activity plays a major role in the pathogenesis of several human diseases including rheumatoid arthritis where IL-8 may act to attract neutrophils into the synovial space of a joint and lead to cartilage damage and destruction. It also appears that Salmonella may induce production of IL-8 by gut epithelium in mammalian models of gastroenteritis (reviewed by Wallis \& Galyov, 2000). These leads to an influx of neutrophils that damage the epithelium allowing bacteria to enter, and as a consequence cause tissue damage and fluid secretion leading to diarrhoea.

In the chicken a number of CXC and CC chemokines have been identified (Kaiser et al., 1999; Hughes \& Bumstead, 2000, Hughes et al., 2001). As in man, the CXC chemokine genes of the chicken are clustered on chromosome 4 (Kaiser et al., 1999; Hughes \& Bumstead, 2000). The chicken chemokine IL8/CAF appears to be the equivalent of mammalian IL-8 in the chicken. Originally termed 9E3/CEF4, this chemokine was the first non-mammalian cytokine cDNA to be cloned (Bedard et al., 1987: Sugano et al., 1987). The protein encoded by this cDNA has $51 \%$ aa identity with human IL-8 (Barker et al., 1993) and 45\% identity with human GRO-a (Stoeckle and Barker, 1990). All three cytokines are members of the same ELR ${ }^{+}$CXC chemokine subfamily, and as such could be expected to be involved in angiogenesis. Consistent with this, 9E3/CEF4 has been shown to play a role in wound healing ( $M$ artins-Green et al., 1991), and can initiate the wound-healing cascade in vivo (M artins-Green \& Feugate, 1998). It is also chemotactic for chicken peripheral blood mononuclear cells and mitogenic for fibroblasts (Barker et al., 1993). Based on these biological activities, 9E3/CEF4 was variously described as the chicken homologue of IL-8 (Barker et al., 1993) or GRO- $\alpha$ (Martins-Green et al., 1991; 1992). How ever, more recently it was proposed that this chemokine be called the chicken chemotactic and angiogenic factor (CAF) (Martins-Green and Feugate, 1998).

At the gene level, CAF corresponds almost exactly to that of human IL-8 and differs from those of other known mammalian CXC chemokine genes, including GRO- $\alpha$ (Kaiser et al., 1999). A number of potential regulatory sequences similar to those found in the human IL-8 promoter, but not in the human GRO- $\alpha$ promoter, have also been identified in the CAF promoter. This evidence suggested that it is the avian orthologue of IL-8 (Kaiser et al., 1999), but on balance, in terms of its biological activity is best described as CAF, although it may still represent the chicken equivalent of mammalian IL-8. M arek's Disease Virus has been shown to encode a CXC chemokine, which has been described in the literature as an IL-8 homologue (vlL-8) (Parcells et al., 2001). Although the viral CXC chemokine (vCXC) has high aa identity with human IL-8 and chicken IL-8/ CAF, there are several important differences between it and known IL-8s which suggest it should by considered to be a vCXC, but not as a vlL-8.

As yet relatively little is known of the role of IL-8/ CAF and other chemokines in avian disease. As in mammals, it has been reported that $\mathrm{S}$. Typhimurium infection produces an influx of heterophils (polymorphonuclear cells) into the gut of chickens (Henderson et al., 1999). This would suggest that Salmonella invasion in the chicken may induce production of chicken IL- 8 which mediates the heterophil influx. Initial experiments using in vitro models seem to confirm this with S. Typhimurium invasion of chicken cells leading to an increase in the levels of chicken IL-8/CAF mRNA (Lazzerine, Kaiser \& W igley, unpublished observations).

\section{Th1, Th2 AND Th3 CYTOKINES}

In mammals T helper lymphocytes are classified by the cytokines they produce. Th1 cells produce cytokines such as IL-2 and IFN- $\gamma$ that lead primarily to the activation 
of macrophages and the development of a cell-mediated immune response. Th2 cells produce IL-4, IL-5 and IL10 that lead to the development of an antibody or humoral response. Th3 cells mainly produce transforming growth factor- $\beta$ (TGF- $\beta$ ) in response to antigen. Their function is less clear, but they appear to play a role in the development of mucosal immune responses. However in birds, this paradigm is not as clear. Although both Th1 and Th3 cytokines have been described, there is, as yet, no clear description of any avian Th2 cytokine. It would, however, seem unlikely that Th2 cytokines do not occur in birds as their immune system behaves broadly as that of mammals and many infections such as Salmonella result in strong humoral responses (Wigley et al., 2001).

\section{IL-2}

M ammalian IL-2 is a $15.5 \mathrm{kDa}$ glycoprotein produced mainly by activated T cells (Th1) and acts mainly to promote $T$ cell growth, but also activates macrophages and affects B cell growth (Gaffen et al., 1998). The IL-2 receptor is a multi-molecular complex consisting of $\alpha, \beta$ and $\gamma$ subunits. Binding of IL-2 to the receptor leads to phosphorylation and signalling through the JAK-STAT pathway as is the case for IL-6.

In birds, both chicken and turkey IL-2 have been described (Sundick \& Gill-Dixon, 1997; Lawson et al., 2000). The chicken IL-2 cDNA was cloned via expression screening for $\mathrm{T}$ cell proliferative activity. It encodes a predicted protein of 143 aa, with a signal sequence of 22 aa and a mature protein of 121 aa (Sundick \& Gill-Dixon, 1997). The predicted protein has almost equal identity with mammalian IL-2 as mammalian IL-15 (e.g. $24.5 \%$ and $23.8 \%$ identity with bovine IL-2 and IL-15 respectively). However, unlike mammalian IL-2, but like mammalian IL-15, the predicted chicken protein has four conserved cysteines that form two intrachain disulphide bonds (Rothwell et al., 2001a). The cDNA was only definitively shown to encode chicken IL-2 when the gene structure, promoter structure and genetic location, chromosome 4, were determined (Kaiser \& Mariani, 1999). Like mammals, glycosylation is not required for the bioactivity of recombinant chicken IL-2 (Stepaniak et al., 1999). Endogenous IL-2 occurs in vitro as a monomer of $14.2 \mathrm{kDa}$ and is secreted by splenocytes within 4 hours of ConA stimulation (Stepaniak et al., 1999). Turkey IL-2 has fairly low identity with chicken IL-2 at the aa level (less than 70\%) but has a very similar promoter and cross-reacts in IL-2 functional bioassays
(Lawson et al., 2000; Rothwell et al., 2001b). Functionally, recombinant chicken IL-2 activates $\gamma \delta$ T cells (Choi et al., 2000). In an experimental Eimeria infection high levels of both $\gamma \delta$ T cells and expression of IL-2 mRNA were found in the gut of chickens (Choi et al., 2000).

Recently established EST databases (Abdrakhmanov et al., 2000; Tirunagaru et al., 2000) contain sequences that resemble the $\gamma$ chain of the mammalian IL-2 receptor.

Several anti-chicken IL-2 mAb have now been produced which neutralise the biological effects of chicken IL-2 (Miyamoto et al., 2001; Rothwell et al., 2001b).

\section{IL-18}

IL-18 in mammals is a factor that induces production of IFN- $\gamma$ (Okamura et al., 1995). It is produced at high levels in the liver by macrophages and Kupffer cells leading to induction of IFN- $\gamma$ and a Th1-type response. It is an important cytokine in the initiation of cell-mediated immune responses. Human IL-18 is a $22.3 \mathrm{kDa} 192$ aa precursor protein that is cleaved, like IL-1, to form a mature active protein of $18.3 \mathrm{kDa}$ and $157 \mathrm{aa}$.

The EST databases contain a partial cDNA for chicken IL-18. This CDNA was cloned in full and expressed by Schneider et al. (2000). The predicted protein is 198 aa in length and has approximately $30 \%$ aa identity with mammalian IL-18s, though the mature form appears to be slightly longer than mammalian IL-18 at 169 aa. A bioassay using a recombinant form of the 169 aa protein has shown induction of IFN- $\gamma$ by stimulated chicken splenocytes indicating it has the same activity as mammalian IL-18. The gene for chicken IL-18 is only a quarter the length of its human equivalent (Kaiser et al., 2001). Turkey IL-18 is remarkably similar to chicken IL-18 (Kaiser, 2002), with $96.4 \%$ aa identity. The fowlpox virus genome has recently been sequenced and contains a number of sequences that predict immune-evasion proteins (Afonso et al., 2000). Amongst these is an IL-18 binding protein. This would be an effective evasion strategy for intracellular pathogens as it would inhibit the development of a Th1 response and hence less effective cell-mediated immunity to clear virally infected cells.

\section{IFN- $\gamma$}

Interferons were so named due to their anti-viral properties. In mammals they consist of two classes: 
Type I interferons (IFN- $\alpha$ and IFN- $\beta$ ) that have welldefined anti-viral activity, and Type II interferon or IFN- $\gamma$ which plays a vital role in macrophage activation and modulation of the immune system, in addition to its anti-viral activity (De M aeyer \& De M aeyer-Guignard, 1998). Type I interferons will be discussed later. In mammals IFN- $\gamma$ is produced primarily by T lymphocytes (Th1) and natural killer cells leading to activation of macrophage antimicrobial activity, an increase in the processing of antigen and the increased expression of Major Histocompatibility Complex (M HC) Class II molecules on macrophages and other cells. IFN- $\gamma$ is also involved in class switching of immunoglobulins. Human IFN- $\gamma$ is a 143 aa monomer encoded by a single gene on chromosome 12 . Glycosylation of the protein varies as a result of to two separate $\mathrm{N}$-glycosylation sites leading to 20 and $25 \mathrm{kDa}$ forms. The IFN- $\gamma$ receptor (IFN- $\gamma \mathrm{R}$ ) consists of a $90 \mathrm{kDa}$ cell surface receptor formed by a homodimer of $\alpha$ chains. The functional receptor also requires a $\beta$ chain, though induction of MHC class II molecules can be achieved through the $\beta$ chain alone. Binding of IFN- $\gamma$ to the receptor leads to signal transduction though the JAKSTAT pathways described previously.

The CDNA for chicken IFN- $\gamma$ encodes a predicted protein of 164 aa (a signal peptide of 19 aa and a mature protein of $145 \mathrm{aa}$ ), with two potential N-glycosylation sites and an estimated MW for the mature protein of $16.8 \mathrm{kDa}$ (Digby \& Low enthal, 1995). It has 32\% identity at the aa level with human IFN- $\gamma$. The chicken IFN- $\gamma$ gene has similar organization to its human equivalent, being a single copy gene with similar intron and exon structure, and maps to chicken chromosome 1 (Kaiser et al., 1998b; Guttenbach et al., 2000).

The coding sequences of IFN- $\gamma$ from four other galliforms (guinea fowl, ring-necked pheasant, Japanese quail and turkey) were recently determined (Kaiser et al., 1998a). The coding regions of IFN- $\gamma$ are highly conserved amongst the galliforms $(93.5-96.7 \%$ and $87.8-97.6 \%$ at the nucleotide and aa levels respectively). This high degree of overall identity at the predicted primary aa sequence level of the protein, including the deduced IFN- $\gamma$ receptor-binding motifs, suggested that IFN- $\gamma$ may be cross-reactive among these species. This has since been shown to be the case for turkey and chicken IFN- $\gamma$ (Law son et al., 2001).

The cDNA for duck IFN- $\gamma$ has $80 \%$ nucleotide identity and $67 \%$ predicted aa identity with chicken IFN- $\gamma$ (Huang et al., 2001). Comparative protein modelling suggested that the predicted threedimensional structures of chicken and duck IFN- $\gamma$ were similar, and subsequent experiments with recombinant proteins showed that the two proteins were functionally cross-reactive (Huang et al., 2001).

As with mammalian IFN- $\gamma$, native chicken IFN- $\gamma$ has potent macrophage activating factor activity that is heat- and pH-labile (Lowenthal et al., 1995). Recombinant chicken IFN- $\gamma$ expressed from $E$. coli or COS cells were poor antiviral agents but strongly stimulated NO secretion and expression of M HC class II in macrophages (Weining et al., 1996). However, baculovirus-derived recombinant chicken IFN- $\gamma$, as well as stimulating macrophages, also had antiviral activity (Lambrecht et al., 1999), and thus is probably a more suitable recombinant for studies into the function of avian IFN- $\gamma$. Again similarly to mammals, chicken type I and type II IFN act synergistically (Sekellick et al., 1998), both in terms of antiviral activity and in their ability to activate macrophages.

Anti-chicken IFN- $\gamma$ mAb have been produced following gene-gun immunisation of mice, and used to develop a quantitative capture ELISA specific for chicken IFN- $\gamma$ (Lambrecht et al., 2000). One of these $\mathrm{mAb}, 1 \mathrm{E} 12$, neutralises the biological effects of both chicken (Lambrecht et al., 2000) and turkey IFN- $\gamma$ (Lawson et al., 2001).

\section{TGF- $\beta$}

TGF- $\beta$ was initially described in mammals on the basis of its ability to transform the phenotype of fibroblast cell lines and was thought to play a role in malignant transformation and the development of tumours (reviewed in Derynck \& Choy, 1998). Subsequently it has been found that TGF- $\beta$ has a large range of biological activities in the immune response and in development. In the immune system TGF- $\beta$ plays an important role in the development of $T$ lymphocytes and has important anti-inflammatory activity. Three forms of TGF- $\beta$ (TGF- $\beta_{1}$ TGF- $\beta_{2}$ and TGF- $\beta_{3}$ ) are found in mammals. The active, mature form of TGF- $\beta$ is a 112 aa monomer, though heterodimeric and homodimeric forms of unknown function are also found.

As in mammals, three forms of TGF- $\beta$ have been cloned from chickens: TGF- $\beta_{4}$ (equivalent to mammalian TGF- $\beta_{1}$ ) (Burt $\&$ Jakowlew, 1992), TGF- $\beta_{2}$ (Jakowlew et al., 1990) and TGF- $\beta_{3}$ (Jakow lew et al., 1988), which have $80 \%, 96-99 \%$ and $97-99 \%$ aa identity respectively with their mammalian homologues. The expression of TGF- $\beta$ in the chicken thymus may regulate the ability of immature thymocytes to progress through the cell cycle and differentiate into mature $\mathrm{CD}^{+}$(a receptor found 
on T lymphocytes) thymocytes (M ukamoto and Kodama, 2000). TGF- $\beta_{4}$ mRNA expression has been shown to increase in the caecal tonsils, spleen and duodenum following E. acervulina infection (Choi et al., 1999a), presumably as part of an anti-inflammatory response.

\section{OTHER CYTOKINES}

\section{Type I IFN}

In mammals the type I interferons, IFN- $\alpha$ and IFN- $\beta$, have anti-viral activity and lead to increased expression of M HC class I molecules (reviewed in De M aeyer $\&$ De $M$ aeyer-Guignard, 1998). Both IFN- $\alpha$ and IFN- $\beta$ consist of a 166 aa monomer in humans and share a common 590 aa, $66 \mathrm{kDa}$ receptor. Interferons activate a range of anti-viral mechanisms including the enzyme oligoadenylate synthetase that leads to the activation of endonucleases that digest viral genomes, the protein kinase PKR which inhibits viral transcription and translation and cytoplasmic $M \times$ proteins which also have anti-viral activity. IFN- $\alpha$ and IFN- $\beta$ also increase expression of $\mathrm{MHC}$ class I molecules. Expression of foreign viral antigen in conjunction with M HC class I mark the virally infected cells as targets for cytotoxic T lymphocytes. Type I IFN may also activate both macrophages and natural killer (NK) cells. Additionally interferons have effects on tumour cells. Proliferation of both normal and tumour cells is reduced by Type I interferons as they act to slow down the cell cycle, oncogene expression is altered and differentiation of tumour cells may also be increased.

The first description of interferons in the chicken was an antiviral activity in conditioned media from chorioallantoic membranes which had been exposed to inactivated influenza virus (Isaacs \& Lindenmann, 1957), and subsequently purified by Lampson et al. (1963) as a 20-34 kDa protein. Little further progress was made in thirty years. Three genes encoding a 193 aa protein with $24 \%$ aa identity with mammalian IFN- $\alpha$, $20 \%$ with mammalian IFN- $\beta$ and only $3 \%$ with mammalian IFN- $\gamma$, termed IFN1 were described in 1994 (Sekellick et al., 1994). A fourth gene encoding a predicted gene product with $57 \%$ aa identity with chicken IFN1was termed IFN2 (Sick et al., 1996). A turkey IFN 1 gene product with a predicted $82 \%$ aa identity to chicken IFN1 and a type I duck interferon with $50 \%$ identity to chicken IFN1 and $61 \%$ identity to IFN2 have also been described (Suresh et al., 1995; Schultz et al., 1995). Differences, particularly in genetic structure and organization, betw een chicken IFN1 and IFN 2 to mammalian IFN- $\alpha$ and IFN- $\beta$ have led to differences of opinion as to whether they are true equivalents and should be named as such. However, IFN1 and IFN2 respond to inducers of Type 1 IFN in a differential way, as do IFN- $\alpha$ and IFN- $\beta$ in mammals and this, along with similarities in binding sites of the promoter, has lead to the proposal that the nomenclature should be IFN- $\alpha$ for IFN1 and IFN- $\beta$ for IFN2 (Lowenthal et al., 2001). Both Type 1 and Type II interferons have been investigated as potential therapeutics in poultry and will be discussed later.

\section{IL-15}

IL-15 in mammals is a T cell growth factor that has 'IL-2-like' activity stimulating the growth of T lymphocytes, NK cells and intestinal epithelium (Kennedy et al., 1998). Human IL-15 is a 114 aa monomer that shares the IL-2R $\beta$ and $\gamma$ chains along with a specific IL$15 \mathrm{R} \alpha$ chain to form the receptor complex. IL-15 induces proliferation, cytokine production and cytotoxic activity of both T cells and NK cells, and induces motility and migration of $\mathrm{T}$ cells. In addition it stimulates proliferation of a number of other cells including B lymphocytes and intestinal epithelial cells. Unlike IL-2 it also stimulates neutrophils, increasing their phagocytic activity.

A chicken IL-15 homologue was identified in the EST libraries and was recently described (Lillehoj et al., 2001; Mejri et al., 2001). The predicted protein has 187 aa and contains a 63-66 aa signal peptide, markedly longer than its mammalian homologues. The predicted $\mathrm{MW}$ of the mature protein is $14.5 \mathrm{kDa}$ encoded by a gene containing six coding exons (Kaiser et al., 2001). There is an earlier report in the literature describing the molecular and functional characterisation of chicken IL15 (Choi et al., 1999b). Unfortunately, closer scrutiny reveals that the cytokine described is in fact the previously mentioned chicken IL-2.

Recently it has been proposed that IL-15 plays a major role in driving spontaneous autoimmune thyroiditis in obese strain (OS) chickens (Kaiser et al., 2002). OS chickens are commonly used as an animal model for the human autoimmune disease Hashimoto's thyroiditis. It is thought that the increased immune activity found in OS chickens may be mediated by IL-15 and that IL-15 may be a factor driving lymphoid infiltration of the thyroid, resulting in inflammation and damage.

\section{IL-16}

IL-16 has been described as a chemoattractant, primarily for CD4 positive T cells, but also for other cells 
including monocytes and eosinophils (reviewed in Antonysamy et al., 1998). M ammalian IL-16 is a 130 aa protein that forms a tetramer. In humans high levels of IL-16 are found in autoimmune diseases or allergic conditions characterized by high numbers of CD4 positive cells. IL-16 also appears to play a major role in the control of HIV replication in human CD4 positive cells. The chicken EST libraries contain sequences that resemble mammalian IL-16.

\section{TNFs}

TNFs are a family of cytokines that produce a range of biological effects. TNF- $\alpha$ or cachetin is a primary regulator of both the immune response and inflammation (Zhang \& Tracey, 1998). TNF- $\alpha$ is produced by macrophages, T cells and NK cells and causes both inflammation and endothelial activation. Although TNF-á is important in activation of immune responses it is implicated in fever and in conditions such as septic shock. TNF- $\beta$ or lymphotoxin is secreted by CD4 T cells and is directly cytotoxic for some cell types. TNF was first described as an anti-tumour protein that induced necrosis in certain tumour types, hence its nomenclature.

Although avian TNF has yet to be cloned, TNF-like activity can be detected in the chicken. After infection with Eimeria (Byrnes et al., 1993a; Zhang et al., 1995) or M arek's disease virus (Qureshi et al., 1990), release of TNF from chicken macrophages can be detected in cross-reactive mammalian cellular cytotoxicity bioassays. Injection of chickens with such TNF-like factors enhances weight loss due to Eimeria infection, which is partially reversible by treatment with antihuman TNF antisera (Zhang et al., 1995). Human recombinant TNF has been shown to cross-react with chicken cells (Leibovich et al., 1987; Butterwith \& Griffin, 1989).

\section{Other cytokines, chemokines and factors}

In addition to the cytokines described previously, several other growth and colony stimulating factors (CSF) have been described in the chicken, as have IL3-like activity and Migration Inhibitory Factor-like activity. As described earlier in the section describing IL-8, a number of chicken CC and CXC chemokines have also been cloned. Among the growth factors described are seven fibroblast grow th factors (FGF): FGF-1, FGF-2, FGF-3, FGF-4, FGF-8, FGF-18 and FGF19 (Borja et al., 1993; Niswander et al., 1994; Han,
1995; Mahmood et al., 1995; Vogel et al., 1996; Ohuchi et al., 2000; Ladher et al., 2000), with between $67 \%$ and $90 \%$ aa identity with their mammalian homologues. Chicken platelet-derived grow th factor (PDGF) CDNA has also been cloned and shows $90 \%$ homology with its human equivalent (Horiuchi et al., 2001). Chicken thrombocytes appear to express only low levels of PDGF mRNA. However, following stimulation with factors involved in haemostasis and wound healing, thrombin and Type 1 collagen, levels of PDG F mRNA increase suggesting that it may play a role in the healing process. Chicken myelomonocytic grow th factor (M GF), necessary for the survival and growth of normal and transformed avian myeloid precursor cells (Leutz et al., 1984; M etz et al., 1991) and stem cell factor (SCF) have been cloned in both the chicken, and also SCF in Japanese quail (Zhou et al., 1993; Petitte \& Kulik, 1996). Other factors with CSF activity have been observed, but their specific identity remains unknown. For example, serum CSF activity is detectable during and immediately after coccidial infection in chickens (Byrnes et al., 1993b), and stromal cell lines secrete factors that induce the proliferation and differentiation of precursor cells in embryonic and haematopoietic tissues (Obranovich \& Boyd, 1996; Siatskas et al., 1996). Kogut et al. (1997) demonstrated the presence of a G-CSF-like factor in lymphokines (ILK) from $T$ cells of birds immunized against Salmonella enteritidis by Western blot using a goat anti-human G-CSF polyclonal antisera. Pretreatment of the ILK with the antisera totally abolished its G-CSF-like activity.

\section{MEASURING AVIAN CYTOKINES}

Determining the levels of human and murine cytokines is relatively easy as there are numbers of commercially available systems, particularly ELISAs, for many cytokines. Perhaps not surprisingly there is only one such commercial product currently available for avian cytokines (an IFN- $\gamma$ ELISA). In addition the relative lack of reliable antibodies to avian cytokines makes development of immunoassays difficult. The development of molecular techniques and in particular reverse transcriptase PCR (RT-PCR) has allow ed cytokine production to be detected without the requirement for the protein, just the cDNA. The recent development of quantitative RT-PCR now allows cytokines to be quantified in chicken. Current methods are briefly described below. 


\section{ELISA and monoclonal antibodies}

ELISA measurement of cytokines would be the ideal choice for most laboratories as they are simple to perform, need little specialized equipment and are relatively inexpensive. How ever, as described previously there are few reliable antibodies available. M onoclonal antibodies (mAbs) to IFN- $\gamma$ and IL- 2 have been produced. The IL-2 mAbs specifically recognise and neutralise chicken IL-2 activity and another panel of mAbs can neutralise chicken IL-2 and one of these, with a rabbit polyclonal antisera against chicken IL-2, has been used to develop a capture ELISA (M iyamoto et al., 2001). Anti-chicken IFN- $\gamma$ mAb have been produced following gene-gun immunisation of mice, and used to develop a quantitative capture ELISA specific for chicken IFN- $\gamma$ (Lambrecht et al., 2000). One of these $\mathrm{mAb}, 1 \mathrm{E} 12$, neutralises the biological effects of both chicken (Lambrecht et al., 2000) and turkey IFN- $\gamma$ (Lawson et al., 2001).

\section{Bioassays}

Bioassays are assays that determine the biological activity of a factor, in this case cytokines. Reliable bioassays have been developed for chicken IL- 6 and IFN- $\gamma$ (van Snick et al., 1986; Lowenthal et al., 1995). The IL- 6 bioassay relies on the cross-reactivity of chicken IL- 6 with murine IL- 6 to maintain the grow th of an IL-6dependent cell line, 7TD1, a mouse hybridoma B cell line. 7TD1 cells are cultured in the presence of the test sample and tritiated thymidine. After six hours of incubation proliferation of the cells is measured by determining the levels of tritiated thymidine incorporated through use of a $\beta$ counter. Levels of IL- 6 are determined through comparison to a standard curve of proliferation determined through 7TD1 cells incubated with recombinant mouse IL-6. The IFN- $\gamma$ bioassay relies on determining the stimulation of the HD11 chicken macrophage cell line (Beug et al., 1979) to produce nitric oxide. The levels of nitric oxide can be easily measured through the Griess assay. The test sample is incubated with the HD11 cells for 24 or 48 hours. The higher the level of IFN- $\gamma$-like activity in the sample, the greater the stimulation of the HD11 cells to produce nitric oxide. Levels are compared with a negative control of unstimulated cells and positive controls stimulated with E. coli LPS. Both assays have been used successfully to determine stimulation of chicken cells with Salmonella (Kaiser et al., 2000). However, both methods are time consuming and technically difficult requiring cell culture and, in particular, the IL-6 bioassay requires the use of radioisotopes.

\section{RT-PCR}

The expression of mRNA in cells or tissues can be detected by RT-PCR. The mRNA transcript is converted to a cDNA through the use of the enzyme reverse transcriptase, the cDNA then being detected through the use of conventional PCR. This is a qualitative method and although it can be made semi-quantitative through densitometry measurement of the PCR products on electrophoresis gels, the technique has been vastly improved by quantitative methods such as real-time RT$P C R$. This technology employs an initial reverse transcriptase step, followed by PCR using fluorescent oligonucleotide probes. The level of product produced can be quantified by the fluorescence during each cycle. Levels of mRNA expressed can then be determined either through relative quantification of RNA in comparison with the mRNA levels of a constitutively expressed or 'housekeeping' gene such as $18 \mathrm{~S}$ rRNA, GAPDH or $\beta$ actin, or through absolute determination using a standard curve of a known quantity of RNA or DNA. In determining cytokine levels in the chicken relative expression has been most commonly used. In our Institute cytokine mRNA levels have been determined using Taqman real-time quantitative RT-PCR technology. This uses a system with fluorescent reporter and quencher dyes at opposing ends of the probe that fluoresce at different wavelengths. This results in an equilibrium between the two fluorescent dyes. During the PCR process the action of Taq polymerase displaces the $5^{\prime}$ end of the fluorescent probe, which can then be degraded by the 5'-3' exonuclease activity of Taq. This leads to the release of the fluorescent dye and the quencher dye into solution. As they are no longer held together by the probe the fluorescence of the reporter can be detected at its optimum fluorescent wavelength. A standard curve can be constructed through the use of threshold $(\mathrm{Ct})$ values, an arbitrary value of fluorescence, and a dilution series of a standard RNA (an RNA known to contain the mRNA of interest). The Ct value is determined as the number of cycles required to reach that level of fluorescence. Cytokine mRNA levels can then be corrected with the Ct values from the 'housekeeping gene' (in our laboratory the 28S rRNA gene is most commonly used) and the relevant standard curves. This technique was used in studies of Salmonella invasion of chicken cells (Kaiser et al., 2000). Levels of cytokine and 285 mRNA were compared between infected and 
Table 2 - Experimental applications of avian cytokines as therapeutic agents or adjuvants.

\begin{tabular}{|c|c|c|c|c|}
\hline Cytokine & Host species & Infectious agent & Comments & Reference \\
\hline IFN- $\alpha$ & Chicken & $\begin{array}{l}\text { Newcastle Disease } \\
\text { Virus (NDV) }\end{array}$ & $\begin{array}{l}\text { Levels of disease reduced in experimental infection } \\
\text { when rIFN- } \alpha \text { administered in drinking water }\end{array}$ & M arcus et al., 1999 \\
\hline IFN- $\alpha$ & Chicken & NDV & $\begin{array}{l}\text { Adjuvant in NDV DNA vaccine delivered in fowlpox } \\
\text { vector. No clear effect. }\end{array}$ & Karaca et al., 1998 \\
\hline IFN- $\alpha$ & Turkey & NDV & Adjuvant in NDV DNA vaccine. Increased antibody titre & Rautenschlein et al., 2000 \\
\hline IFN- $\alpha$ & Chicken & $\begin{array}{l}\text { Tetanus toxoid (TT) } \\
\text { Infectious bursal disease } \\
\text { virus (IBDV) }\end{array}$ & $\begin{array}{l}\text { Administration of IFN increased antibody titres to } \\
\text { tetanus toxoid but not IBDV }\end{array}$ & Schijns et al., 2000 \\
\hline IFN- $\alpha$ & Chicken & Rous Sarcoma Virus (RSV) & Reduction of RSV-induced tumours & Plachy et al., 1999 \\
\hline $\mathrm{IFN}-\gamma$ & Turkey & NDV & $\begin{array}{l}\text { In ovo vaccination of IFN- } \gamma \text { NDV DNA vaccine in } \\
\text { fowlpox vector. M ore rapid antibody response and } \\
\text { increased protection to NDV challenge }\end{array}$ & Rautenschlein et al., 1999 \\
\hline $\mathrm{IFN}-\gamma$ & Chicken & Sheep red blood cells & Increased immune response & Lowenthal et al., 1998 \\
\hline Type I \& II IFN & Chicken & $\begin{array}{l}\text { Marek's disease virus } \\
\text { (MDV) }\end{array}$ & $\begin{array}{l}\text { In vitro inhibition of MDV replication and suppression } \\
\text { of MDV-encoded proteins in virally infected cells }\end{array}$ & Heller et al., 1997 \\
\hline IL-1 $\beta$ & Chicken & Tetanus toxoid (TT) & No effect when administered as an adjuvant with $\Pi$ & Schijns et al., 2000 \\
\hline $\begin{array}{l}\text { Undefined } \\
\text { immune } \\
\text { lymphokines } \\
\text { (ILK) }\end{array}$ & Chicken & $\begin{array}{l}\text { Salmonella Enterica } \\
\text { Serovar Enteritidis }\end{array}$ & $\begin{array}{l}\text { Administration with ILK inhibits Salmonella } \\
\text { colonization of the gut }\end{array}$ & Kogut et al., 1997 \\
\hline
\end{tabular}

uninfected cells and differences in levels of cytokine mRNA expression determined after correction with the 28S rRNA mRNA levels.

Although Taqman is a powerful technique to measure expression of cytokine mRNA, or any other chicken gene, it must be remembered that this may not necessarily reflect protein levels. In the case of the Salmonella infection studies it was possible to compare the IL-6 and IFN- $\gamma$ levels to bioassay activity, which correlated extremely well. Additionally the cost of such technology is very high, both in terms of equipment and consumables such as the probes. It does, nevertheless, represent a huge advance in our ability to study cytokines in disease processes.

\section{CYTOKINES AS THERAPEUTIC AGENTS AND A VACCINE ADJ UVANTS}

Extensive experimental and clinical studies have been made on the therapeutic use of cytokines in mammals in conditions ranging from infectious disease to cancer, often with mixed results. In comparison their use in avian species has been limited, though this is being increasingly explored and is summarized in Table 2 .

As can be seen in the table, the use of interferons as adjuvants or therapeutics has been most widely investigated, with some success. One particular approach of interest is to incorporate the gene encoding the cytokine of interest into a DNA vaccine or into a viral or bacterial vaccine vector. For example, the incorporation of IFN- $\gamma$ into a Newcastle Disease vaccine carried in a fowlpox vector in turkeys (Rautenschlein et al., 1999). This approach led to a more rapid onset of antibody production and increased protection to subsequent disease challenge. Such an approach may also be effective in diseases such as fow I typhoid. During Salmonella enterica serovar Gallinarum infection, survival within macrophages is crucial to disease progression (Jones et al., 2001). Incorporation of IL-18 into an attenuated vaccine strain such as the $9 R$ vaccine 
(Smith, 1956) could cause an increased Th1-type response in turn leading to the production of IFN- $\gamma$ and macrophage activation, with subsequent clearance of Salmonella from macrophages. A possible problem with such an approach is that interference from a protective antibody response may occur, reducing the long-term efficacy of the vaccine.

\section{CONCLUSIONS}

Although the study of cytokines and chemokines in avian species is still in its infancy when compared to that of mammals, huge strides have been made in recent years. The use of molecular techniques is enabling the role of cytokines in the pathogenesis of diseases as diverse as salmonellosis and thryroiditis to be determined. Although the costs of using techniques such as quantitative RT-PCR are still too high for their use in many laboratories, these costs are gradually falling. More antibodies to avian cytokines are also likely to be developed in coming years, allowing more ELISAs to determine cytokines to be developed. As can be seen, cytokines play a vital role in the development of immunity to a range of infections, and their use as therapeutics in both infectious and noninfectious disease is likely to be investigated in greater depth and with a larger range of cytokines. Their potential use as adjuvants, particularly incorporated within DNA vaccines or vaccine vectors, is also being investigated. An increased understanding of the immune response in birds is likely to be achieved through our increased ability to study its component parts, such as cytokines, allowing the development of more effective vaccines and vaccination strategies. It is also likely that gaps in our knowledge regarding avian cytokines will be filled, particularly the Th2 cytokines, as the genome of the chicken and EST databases are explored. This will lead to further understanding of the role the immune system, and in particular cytokines, play in avian health and disease.

\section{REFERENCES}

Abdrakhmanov I, Lodygin D, Geroth P, Arakawa H, Law A, Plachy J, Korn B, Buerstedde JM. A large database of chicken bursal ESTs as a resource for the analysis of vertebrate gene function. Genome Research 2000; 10: 2062-2069.

Afonso CL, Tulman ER, Lu Z, Zsak L, Kutish GF, Rock DL. The genome of fowlpox virus. Journal of Virology 2000; 74: 3815-3831.

Antonysamy MA, Lotze MT, Tahara $\mathrm{H}$, Thomson AW. Interleukins, 16,17, and 18. In: AW Thomson (editor). The Cytokine Handbook $3^{\text {rd }}$ edition. Academic Press, San Diego. 1998; p.465-489.

Barker KA, Hampe A, Stoeckle MY, Hanafusa H. Transformationassociated cytokine 9E3/CEF4 is chemotactic for chicken peripheral blood mononuclear cells. Journal of Virology 1993; 67; 3528-3533.

Beug $\mathrm{H}$, von Kirchbach A, Doederlein G, Conscience JF, Graf T. Chicken hematopoietic cells transformed by seven strains of defective avian leukemia viruses display three distinct phenotypes of differentiation. Cell 1979; 18: 375-390.

Borja AZM, Zeller R, M eijers C. Expression of alternatively spliced bFGF coding exons and antisense mRNAs during chicken embryogenesis. Developmental Biology 1993; 157, 110-118.

Burt DW, Jakowlew SB. A new interpretation of a chicken transforming growth factor- $b_{4}$ complementary DNA. Molecular Endocrinology 1992; 6: 989-992.

Butterwith SC, Griffin HD. The effects of macrophage-derived cytokines on lipid metabolism in chicken (Gallus domesticus) hepatocytes and adipocytes. Comparative Biochemistry Physiology 1989; 97B: 721-724.

Byrnes S, Eaton R, Kogut M . (1993a). In vitro interleukin-1 and tumor necrosis factor-a production by macrophages from chickens infected with either Eimeria maxima or Eimeria tenella. International Journal of Parasitology 1993a; 23, 639-645.

Byrnes S, Emerson K, Kogut M. Dynamics of cytokine production during coccidial infections in chickens: colony stimulating factors and interferon. FEM S Immunology M edical M icrobiology 1993b; 6: 45-52.

Choi KD, Lillehoj HS, Zalenga DS. Changes in local IFN-gamma and TGF-beta4 mRNA expression and intraepithelial lymphocytes following Eimeria acervulina infection. Veterinary Immunolology and Immunopathology 1999a; 71: 263-275.

Choi KD, Lillehoj HS, Song KD, Han JY. Molecular and functional characterization of chicken IL-15. Developmental and Comparative Immunology 1999b; 23: 165-177.

Choi KD, Lillehoj HS. Role of chicken IL-2 on $\gamma \delta$ T-cells and Eimeria acervulina-induced changes in intestinal IL-2 mRNA expression and $\gamma \delta$ T-cells. Veterinary Immunology and Immunopathology 2000; 73: 309-321.

De Mayer EM, De Mayer-Guinard J. Interferons. In: AW Thomson (editor). The Cytokine Handbook $3^{\text {rd }}$ edition.. Academic Press, San Diego. 1998. p.491-515.

Derynk R, Choy L. Transforming growth factor- $\beta$ and its receptors In: AW Thomson (editor).The Cytokine Handbook. $3^{\text {rd }}$ edition.. Academic Press, San Diego. 1998. p.593-635.

Digby MR, Lowenthal JW. Cloning and expression of the chicken interferon- $\gamma$ gene. Journal of Interferon Cytokine Research 1995; 15, 939-945.

Dinarello CA. Interleukin-1. In: AW Thomson (editor). The Cytokine Handbook. $3^{\text {rd }}$ edition. Academic Press, San Diego. 1998. p.35-71. 
Gaffen SL, Goldsmith MA, Greene WC. Interleukin-2 and the Interleukin-2 receptor. In: AW Thomson (editor).The Cytokine Handbook $3^{\text {rd }}$ edition. Academic Press, San Diego. 1998. p.73-131.

Guida S, Heguy A, Melli M. The chicken IL-1 receptor: differential evolution of the cytoplasmic and extracellular domains. Gene 1992; 111: 239-243.

Guttenbach M, Nanda I, Brickell PM, Godbout R, Staeheli P, Zehner ZE, Schmid $M$. Chromosomal localisation of the genes encoding ALDH, BMP-2, R-FABP, IFN- $\gamma$, RXR- $\gamma$, and VIM in chicken by fluo rescence in situ hybridization. Cytogenetics Cell Genetics 2000; 88: $266-271$.

Han JK. M olecular-cloning of a chicken-embryo fibroblast-growthfactor-1 CDNA and its expression during early embryogenesis. Molecular Cell 1995; 5: 579-585.

Heggen CL, Qureshi MA, Edens FW, Barnes HJ. Alterations in macrophage-produced cytokines and nitrite associated with poult enteritis and mortality syndrome. Avian Diseases 2000; 44: 59-65.

Heller ED, Levy AM, Vaiman R, Schwartsburd B. Chicken-embryo fibroblasts produce two types of interferon upon stimulation with Newcastle disease virus. Veterinary Immunolology and Immunopathology 1997; 57: 289-303.

Henderson SC, Bounous DI, Lee M D. Early events in the pathogenesis of avian salmonellosis. Infection and Immunity 1999; 67: 3580-3586.

Hirano T. Interleukin 6. In: AE Thomson (editor). The Cytokine Handbook $3^{\text {rd }}$ edition. Academic Press, San Diego. 1998; p.197-227.

Horiuchi $\mathrm{H}$, Inoue T, Furusawa $\mathrm{S}, \mathrm{M}$ atsuda $\mathrm{H}$. Characterisation and expression of three forms of cDNA encoding chicken platelet-derived growth factor-A chain. Gene 2001; 272: 181-190.

Huang A, Scougall CA, Lowenthal JW, Jilbert AR, Kotlarski I. Structural and functional homology between duck and chicken interferon-gamma. Developmental and Comparative Immunology 2001; 25: 55-68.

Hughes S, Bumstead N. The gene encoding the chicken chemokine K60 maps to chromosome 4. Animal Genetics 2000; 31: 418-419.

Hughes S, Haynes A, O'Regan M, Bumstead N. Identification, mapping and phylogenetic analysis of three novel chicken CC chemokines. Immunogenetics 2001; 58: 674-683.

Isaacs A, Lindenmann J. Virus interference. I. The interferons. Proceedings Royal Society (London) B 1957; 147: 258-267.

Jakowlew SB, Dillard PJ, Kondaiah P, Sporn MB, Roberts AB. Complementary deoxyribonucleic acid cloning of a novel transforming growth factor- $\beta$ messenger ribonucleic acid from chick embryo chondrocytes. M olecular Endocrinology 1988; 2: 747-755.

Jakowlew SB, Dillard PJ, Sporn MB, Roberts AB. Complementary deoxyribonucleic acid cloning of an mRNA encoding transforming grow th factor- $\beta$ from chicken embryo chondrocytes. Growth Factors 1990; 2: 123-133.
Jones MA, Wigley P, Page KL, Hulme SD, Barrow PA. Salmonella enterica serovar Gallinarum requires the Salmonella pathogenicity island 2 type III secretion system but not the Salmonella pathogenicity island 1 type III secretion system for virulence in chickens. Infection and Immunity 2001; 69: 5471-5476.

Kaiser P, Sonnemans D, Smith LM. (1998a). Avian IFN- $\gamma$ genes: sequence analysis suggests probable cross-species reactivity among galliforms. Journal of Interferon Cytokine Research 1998a; 18: 711-719.

Kaiser P, Wain HM, Rothwell L. Structure of the chicken interferon$\mathrm{g}$ gene, and comparison to mammalian homologues. Gene 1998b; 207: 25-32.

Kaiser $\mathrm{P}, \mathrm{M}$ ariani P. Promoter sequence, exon:intron structure, and synteny of genetic location show that a chicken cytokine with T-cell proliferative activity is IL2 and not IL15. Immunogenetics 1999; 49: 26-35.

Kaiser P, Hughes S, Bumstead N. The chicken 9E3/CEF4 CXC chemokine is the avian orthologue of IL8 and maps to chicken Chromosome 4 syntenic with genes flanking the mammalian chemokine cluster. Immunogenetics 1999; 49: 673-684.

Kaiser P, Rothwell L, Galyov EE, Barrow PA, Burnside J, Wigley P. Differential cytokine expression in avian cells in response to invasion by Salmonella typhimurium, Salmonella enteritidis and Salmonella gallinarum. M icrobiology 2000; 146: 3217-3226.

Kaiser P, Bumstead N, Goodchild M, Atkinson D, Rothwell L. Characterising chicken cytokine genes - IL-1 $\beta$, IL-6, IL-15 and IL-18. In: KA Schat (editor). Current Progress on Avian Immunology Research: Proceedings of the $7^{\text {th }}$ Avian Immunology Research Group, Ithaca, NY. American Association of Avian Pathologists, Inc., Pennsylvania, 2001. p.27-32.

Kaiser P, Rothw ell L, Vasicek D, Hala K. A role for IL-15 in driving thr onset of spontaneous autoimmune thyroiditis? Journal of Immunology 2002; 168: 4216-4220.

Kaiser P. Turkey interleukin-18 (IL18) has high identity with chicken IL18, and contains a canonical polyadenylation site in its 3' UTR absent in that of the chicken. Developmental and Comparative Immunology 2002; 26: 681-687.

Karaca K, Sharma JM, W inslow BJ, Junker DE, Reddy S, Cochran M, $M$ cM illen J. Recombinant fow Ipox viruses coexpressing chicken type I IFN and New castle disease virus HN and F genes: influence of IFN on protective efficacy and humoral responses of chickens following in ovo or post-hatch administration of recombinant viruses. Vaccine 1998; 16: 1496-1503.

Kennedy MK, Park LS, Paxton RJ. Interleukin-15. In: AW Thomson (editor).The Cytokine Handbook $3^{\text {rd }}$ edition. Academic Press, San Diego. 1998. p.443-463.

Klasing KC, Peng RK. Soluble type-I interleukin-1 receptor blocks chicken IL-1 activity. Developmental and Comparative Immunology 2001; 25: 345-352.

Kogut MH, Moyes R, Deloach JR. Neutralization of G-CSF inhibits 
ILK-induced heterophil influx: granulocyte-colony stimulating factor mediates the Salmonella enteritidis-immune lymphokine potentiation of the acute avian inflammatory response. Inflammation 1997; 21: 9-25.

Koshlukova S, Finn TP, Nishi R, Halvorsen SW. Identification of functional receptors for ciliary neurotrophil factor on chick ciliary ganglion neurons. Neuroscience 1996; 72: 821-832.

Ladher RK, Anakwe KU, Gurney AL, Schoenwolf GC, Francis-West $\mathrm{PH}$. Identification of synergistic signals initiating inner ear development. Science 2000; 290: 1965-1968.

Lambrecht B, Gonze M, M eulemans G, van den Berg TP. Production of antibodies against chicken interferon- $\gamma$ : demonstration of neutralising activity and development of a quantitative ELISA. Veterinary Immunology Immunopathology 2000; 74: 137-144.

Lambrecht B, Gonze M, M orales D, M eulemans G, van den Berg TP. Comparison of biological activities of natural and recombinant chicken interferon- $\gamma$. Veterinary Immunology Immunopathology 1999; 70, 257-267.

Lampson GP, Tytell AA, Nemes M M, Hilleman M R. Purification and characterization of chick embryo interferon. Proceedings Society Experimental Biology and M edicine 1963; 112, 468-478.

Laurent F, M ancassola R, Lacroix S, Menezes R, Naciri M. Analysis of chicken mucosal immune response to Eimeria tenella and Eimeria maxima infection by quantitative reverse transcription-PCR. Infection and Immunity 2001; 69: 2527-2534.

Lawson S, Rothwell L, Kaiser P. Turkey and chicken interleukin-2 cross-react in in vitro proliferation assays despite limited aa sequence identity. Journal of Interferon Cytokine Research 2000; 20: $161-170$

Lawson S, Rothwell L, Lambrecht B, Howes K, Venugopal K, Kaiser P. Turkey and chicken interferon- $\gamma$, which share high sequence identity, are biologically cross-reactive. Developmental and Comparative Immunology 2001; 25: 69-82.

Leibovich SJ, Polverini PJ, Shepard HM, Wiseman DM, Shively V, Nuseir N. M acrophage-induced angiogenesis is mediated by tumour necrosis factor-a. Nature 1987; 329: 630-632.

Leutz A, Berg H, Graf T. Purification and characterisation of CM GF, a novel chicken myelomonocytic grow th factor. Embo Journal 1984; 3: 3191-3197.

Lillehoj HS, Min W, Choi KD, Babu US, Burnside J, Miyamoto T, Rosenthal BM, Lillehoj EP. Molecular, cellular, and functional characterization of chicken cytokines homologous to mammalian IL-15 and IL-2. Veterinary Immunology and Immunopathology 2001; 82: $229-244$.

Lowenthal JW, Digby MR, York JJ. Production of interferon- $\gamma$ by chicken T cells. Journal of Interferon Cytokine Research 1995; 15: 933-938.

Lowenthal JW, O'Neil TE, Broadway M, Strom ADG, Digby MR, Andrew $M$, York JJ. Coadministration of IFN- $\gamma$ enhances antibody responses in chickens. Journal of Interferon Cytokine Research 1998; 18: $617-622$

Lowenthal JW, Staeheli P, Schultz U, Sekellick MJ, Marcus PI. Nomenclature of avian interferon proteins. Journal of Interferon and Cytokine Research 2001; 21: 547-549.

Lynagh GR, Bailey M, Kaiser P. Interleukin- 6 is produced during both murine and avian Eimeria infections. Veterinary Immunology and Immunopathology 2000; 76: 89-102.

Mahmood R, Kiefer P, Guthrie S, Dickson C, Mason I. Multiple roles for FGF-3 during cranial neural development in the chicken. Development 1995; 121: 1399-1410.

M arcus $\mathrm{PI}$, van der Heide L, Sekellick MJ. Interferon action on avian viruses: I. Oral administration of chicken interferon- $\alpha$ ameliorates New castle disease. Journal of Interferon Cytokine Research. 1999; 19: 881-885.

Martins-Green M, Aotakikeen A, Hjelmeland LM, Bissell MJ. The $9 \mathrm{E} 3$ protein - immunolocalization in vivo and evidence for multiple forms in culture. Journal of Cell Science 1992; 101: 701-707.

M artins-Green M, Tilley C, Schwarz R, Hatier C, Bissell MJ. Woundfactor-induced and cell-cycle phase-dependent expression of 9E3/ CEF4, the avian GRO gene. Cell Regulation 1991; 2: 739-952.

Martins-Green $M$, Feugate JE. The $9 E 3 / C E F 4$ gene product is a chemotactic and angiogenic factor that can initiate the woundhealing cascade in vivo. Cytokine 1998; 10: 522-535.

M ejri I, Schuster K, Gobel T. Cloning and expression of the chicken IL-15 homologue. In: C Fossum, E Wattrang, GV UIm (editors). Proceedings of the $6^{\text {th }}$ International Veterinary Immunology Symposium. 1995. p.96.

M etz T, Graf T, Leutz A. Activation of cM GF expression is a critical step in avian myeloid leukemogenesis. Embo Journal 1991; 10: 837-844.

Miyamoto T, Lillehoj HS, Sohn EJ, Min W. Production and characterization of monoclonal antibodies detecting chicken interleukin-2 and the development of an antigen capture enzymelinked immunosorbent assay. Veterinary Immunology and Immunopathology 2001; 80: 245-257.

Mukamoto $\mathrm{M}$, Kodama $\mathrm{H}$. Regulation of early chicken thymocyte proliferation by transforming growth factor- $\beta$ from thymic stromal cells and thymocytes. Veterinary Immunology Immunopathology 2000; 77: 121-132.

Niswander L, J effrey S, Martin JR, Tickle C. A positive feedback loop coordinates growth and patterning in the vertebrate limb. Nature 1994; 371: 609-612.

Obranovich TD, Boyd RL. A bursal stromal derived cytokine induces proliferation of MHC class II bearing cells. Developmental Comparative Immunology 1996; 20: 61-75.

Ohuchi H, Kimura S, Watamoto M, Itoh N. Involvement of fibroblast growth factor (FGF)18-FGF8 signaling in specification of left-right 
asymmetry and brain and limb development of the chick embryo. Mechanisms of Development 2000; 95: 55-66.

Okamura H, Tsutsi H, Komatsu T, Yutsudo M, Hakura A, Tanimoto T, Torigoe K, Okura T, Nukada Y, Hattori K, Akita K, Namba M, Tanabe F, Konishi K, Fukada S, Kurimoto M. Cloning of a new cytokine that induces IFN-gamma production by T cells. Nature 1995; 378: 88-91.

Parcells MS, Lin S-F, Dienglewicz RL, M ajerciak V, Robinson DR, Chen $\mathrm{H}-\mathrm{C}$, Wu Z, Dubyak GR, Brunovskis P, Hunt HD, Lee LF, Kung H-J. $M$ arek's disease virus (MDV) encodes an interleukin- 8 homolog (vIL8): characterization of the VlL- 8 protein and a vlL- 8 deletion mutant MDV. Journal of Virology 2001; 75: 5159-5173.

Petitte JN, Kulik MJ. Cloning and characterisation of CDNAs encoding two forms of avian stem cell factor. Biochemistry Biophysics Acta 1996; 1307: 149-151.

Plachy J, Weining KC, Kremmer E, Puehler F, Hala K, Kaspers B, Staeheli P. Protective effects of type I and type II interferons tow ard Rous Sarcoma virus-induced tumors in chickens. Virology 1999; 256: 85-91.

Rautenschlein S, Subramanian A, Sharma JM. Bioactivities of a tumour necrosis-like factor released by chicken macrophages. Developmental and Comparative Immunology 1999; 23: 629-640.

Rautenschlein S, Sharma JM, Winslow BJ, McM illen J, Junker D, Cochran M. Embryo vaccination of turkeys against Newcastle disease infection with recombinant fowlpox virus constructs containing interferons as adjuvants. Vaccine 2000; 18, 426-433.

Rothwell L, Gill A, Kaiser P. Properties and biological activity of chicken interleukin-2. In: C Fosssum, E Wattrang, GV UIm (editors). Proceedings of the $6^{\text {th }}$ International Veterinary Immunology Symposium. 2001a. p. 97.

Rothwell L, Hamblin AS, Kaiser P. Production and characterisation of monoclonal antibodies specific for chicken interleukin-2. Veterinary Immunology and Immunopathology 20001b; 83: 149-160.

Schijns VECJ, Weining KC, Nuijten P, Rijke EO, Staeheli P. Immunoadjuvant activities of $E$. coli - and plasmid-expressed recombinant chicken IFN- $\alpha / \beta$, IFN-g and IL-1 $\beta$ in 1-day- and 3-weekold chickens. Vaccine 2000; 18: 2147-2154.

Schneider K, Puehler F, Baeuerle D, Elvers S, Staeheli P, Kaspers B, Weining KC. CDNA cloning of biologically active chicken interleukin18. Journal of Interferon Cytokine Research 2000; 20: 879-883.

Schneider K, Klaa R, Kaspers B, Staeheli P. Chicken interleukin-6 CDNA structure and biological properties. European Journal of Biochemistry 2001; 268: 4200-4206.

Sekellick MJ, Ferrandino AF, Hopkins DA, Marcus PI. Chicken interferon gene: cloning, expression, and analysis. Journal of Interferon Cytokine Research 1994; 14: 71-79.

Sekellick MJ, Lowentahl JW, O'Neil TE, Marcus PI. Chicken interferon types I and II enhance synergistically the antiviral state and nitric oxide secretion. Journal of Interferon Cytokine Research 1998; 18: 407-414.
Siatskas C, M cWaters PG, Digby M, Lowentahl JW, Boyd RL. In vitro characterization of a novel avian haematopoietic growth factor derived from stromal cells. Developmental and Comparative Immunology 1996; 20: 139-156.

Sick C, Schultz U, Staeheli P. A family of genes coding for two serologically distinct chicken interferons. Journal of Biological Chemistry 1996; 271: 7635-7639.

Smith HW. The use of live vaccines in experimental Salmonella gallinarum infection with observations on their interference effect. Journal of Hygiene 1956; 54: 419-432.

Stepaniak JA, Shuster JE, Hu W, Sundick RS. Production and in vitro characterization of recombinant chicken interleukin-2. Journal of Interferon Cytokine Research 1999; 19: 515-526.

Stoeckle MY, Barker KA. Two burgeoning families of platelet factor 4-related proteins: mediators of inflammatory responses. New Biology 1994; 2: 313-323.

Sundick RS, Gill-Dixon C. A cloned chicken lymphokine homologous to both mammalian IL-2 and IL-15. Journal of Immunology 1997; 159: $720-725$.

Tomai MA, Gibson SJ, Imbertson LM, M iller RL, M yhre PE, Reiter MJ, Wagner TL, Tamulinas CB, Beaurline JM, Gerster JF, et al. Immunomodulating and antiviral activities of the imidazoquinoline S-28463. Antiviral Research 1995; 28: 253-264.

Vogel A, Rodriguez C, Izpisua-Belmonte JC. Involvement of FGF-8 in initiation, outgrowth and patterning in the vertebrate limb. Development 1996; 122: 1737-1750.

Wallis TS, Galyov EE. M olecular basis of Salmonella-induced enteritis. Molecular Microbiology 2000; 36: 997-1005.

Weining KC, Schultz U, M unster U, Kaspers B, Staeheli P. Biological properties of recombinant chicken interferon-g. European Journal of Immunology 1996; 26: 2440-2447.

Weining KC, Sick C, Kaspers B, Staeheli P. A chicken homologue of mammalian interleukin-1b: cDNA cloning and purification of active recombinant protein. European Journal of Biochemistry 1998; 258: 994-1000.

Wigley P, Berchieri Jr A, Page KL, Smith AL, Barrow PA. Salmonella enterica serovar Pullorum persists in splenic macrophages and in the reproductive tract during persistent, disease-free carriage in chickens. Infection Immunity 2001; 69: 7873-7879.

Wuyts A, Proost P, Van Damme J. Interleukin-8 and other CXC chemokines. In: AW Thomson (editor). The Cytokine Handbook $3^{\text {rd }}$ edition. Academic Press, San Diego. 1998. p.229-269.

Zhang M, Tracey KJ. Tumor necrosis factor. In: AW Thomson (editor). The Cytokine Handbook $3^{\text {rd }}$ edition. Academic Press, San Diego. 1998. p.517-547.

Zhang SP, Lillehoj HS, Ruff MD. In vivo role of tumor necrosislike factors in Eimeria tenella infection. Avian Diseases 1995; 39: 859-866.

Zhou JH, Ohtaki M, Sakurai M. Sequence of a cDNA encoding chicken stem cell factor. Gene 1993; 127: 269-270. 